\title{
Host plants of insect-induced galls in areas of cerrado in the state of Goiás, Brazil
}

Walter Santos de Araújo ${ }^{1,2,4,5}$, Isadora Portes Abraham Silva ${ }^{2}$, Benedito Baptista dos Santos² and Vera Lúcia Gomes-Klein ${ }^{3,4}$

Received: 17 November, 2010. Accepted: 19 July, 2013

\begin{abstract}
Most studies of the interactions between plants and gall-inducing (galling) insects have focused on the entomological aspects, few having addressed the diversity of galls in relation to the characteristics of the host plants. The objective of this study was to analyze the richness and composition of the community of host plants of galls in areas of cerrado (savanna) in the state of Goiás, Brazil. To that end, we inventoried the galls in different regions of the state and within various types of vegetation formations, between 2005 and 2007. We registered 80 gall morphotypes in 58 species of host plants ( 30 families and 47 genera). The host family with highest diversity of galls was Fabaceae, with 17 morphotypes, followed by Styracaceae, with seven. In the cerrado, Fabaceae is the plant family with the highest number of species. Our results show that the composition of a plant community is a determinant of the distribution of galling insects. At the family or genus level, the presence of certain taxa increases the species richness of the population of galling insects.
\end{abstract}

Key words: botanical families; floristic composition; galling insects; superhosts

\section{Introduction}

Insect-induced galls are caused by interactions between insects and plants that results in hypertrophy or hyperplasia of plant tissues (Fernandes et al. 1988). The relationships between species of gall-inducing (galling) insects and their host plants are intimate and specific (Carneiro et al. 2009), each gall morphotype being unique (Stone \& Schönrongger 2003). Most studies investigating this type of insect-plant interaction have examined it from an entomological point of view, with various objectives, such as to characterize distribution patterns and quantify diversity (Fernandes \& Price 1988; Cuevas-Reyes et al. 2004); to identify preferences related to host plants (Espírito-Santo \& Fernandes 2007; Araújo \& Santos 2009a); and to elucidate ecological and evolutional dynamics (Price 2005; Espírito-Santo et al. 2007). Few studies have addressed the diversity of galls by investigating the characteristics of the host plants.

Species of host plants of insect-induced galls have been identified in many botanical families (Gagné 1994). Certain characteristics of those families might increase the species richness of the population of galling insects. For example, the size of the plant family (Fernandes 1992; Mendonça 2007; Araújo 2011) and the geological age of the family (Fernandes 1992), as well as the presence of species or genera that present "superhost" phenotypes (Vedtman \& McGeoch 2003; Araújo et al. 2013), can be determinants of galling insect species richness. The systematic investigation of the composition of the host plant communities is fundamental to demonstrating the importance of each of these factors.

The families that have been shown to harbor the greatest diversity of galls in Brazil are Asteraceae, Fabaceae and Myrtaceae (Mendonça 2007). Those families have been identified in studies of different regions, vegetation formations and biomes within the country. Although such studies have focused on various regions of the country, the floristic patterns of the host plants of galls in Brazil remain practically unknown. Therefore, the objective of the present study was to analyze the effects that the richness and composition of the community of host plants has on galling insect species richness in areas of cerrado (savanna) within the state of Goiás.

\footnotetext{
${ }^{1}$ Instituto de Pesquisas Ambientais e Ações Conservacionistas, Departamento de Ecologia, Goiânia, GO, Brazil

${ }^{2}$ Universidade Federal de Goiás, Instituto de Ciências Biológicas, Departamento de Biologia Geral, Laboratório de Entomologia, Goiânia, GO, Brazil

${ }^{3}$ Universidade Federal de Goiás, Instituto de Ciências Biológicas, Departamento de Biologia Geral Laboratório de Morfologia e Taxonomia Vegetal, Goiânia, GO, Brazil

${ }^{4}$ Universidade Federal de Goiás, Pós-Graduação em Ecologia e Evolução, Goiânia, GO, Brazil

${ }^{5}$ Author for correspondence: walterbioaraujo@yahoo.com.br
} 


\section{Material and methods}

\section{Study area}

The study was carried out in different areas of the state of Goiás, which is in the central-west region of Brazil, within a macro-region dominated by cerrado. According to the Köppen climate classification system, the climate of the region is type Aw, tropical hot and humid, with rainy summers (October through March) and dry winters (April through September). The average annual rainfall is $1500 \mathrm{~mm}$ (range, 750-2000 $\mathrm{mm}$ ), and the average temperature in the coolest month is above $18^{\circ} \mathrm{C}$ (Ribeiro \& Walter 1998).

\section{Methodology and data analysis}

Data were compiled from a series of inventories related to gall host plants and the diversity of gall morphotypes, conducted between 2005 and 2007 in areas of the Serra dos Pireneus State Park, near the city of Pirenópolis; the Itanhangá quarter of the (capital) city of Goiânia, a semiurban area; another semi-urban area within the city of Caldas Novas; and the campus of the Federal University of Goiás, in Goiânia. The characteristics of the four study sites are shown in Tab. 1. These semi-urban areas are remnants of native vegetation, generally located on tracts of land or housing developments that are only partially inhabited.

The sampling was done through censuses and active searches in each of the vegetation formations of the studied areas (Fernandes et al. 1988). We sampled every plant that hosted galls, including trees, bushes and shrubs. All of the observed galls and host plants were described, registered, photographed and identified. Three or four exemplars of each host plant were collected, part of the material being sent for botanical identification, the remainder being used in order to create a photographic record and written description, as well as to obtain the adult insect, in the laboratory.

From the data collected at the various sites, we compiled a list of host plants and galls, including the morphological descriptions of the latter. The relationship between the size of the plant family and galling insect species rich- ness was tested through simple linear regression analysis. Information about the diversity and size of botanic taxa was obtained from the Flora Vascular do Bioma Cerrado ("Vascular Flora of the Cerrado Biome") inventory taken by Mendonça et al. (1998). The families of host plants were categorized according to the classification system established in the Angiosperm Phylogeny Group II guidelines (APG II 2003).

\section{Results and discussion}

We registered 80 morphotypes of galls in 58 species of host plants (Tab. 2). Those species were distributed among 30 families and 47 genera. Many of the gall morphotypes sampled represent new records for the neotropical region. Some of the galls found are depicted in Fig. 1.

We observed a relevant pattern of galling insect species richness, by taxonomic level. At the order level, the plant species that were hosts of galls were distributed across 17 orders (Fig. 2a), those with the highest numbers of host species and galls being Fabales, Malpighiales and Myrtales. Within the order Fabales, which is particularly species rich in the tropics, especially in the neotropical region (Mendonça et al., 1998), we identified 12 host species (all belonging to the family Fabaceae) and 17 gall morphotypes. The orders Malpighiales and Myrtales also showed great species richness among the population of galling insects, each with 13 gall morphotypes (Fig. 2a), on plant species belonging to one of seven and three families, respectively. Fabales, Malpighiales and Myrtales collectively accounted for 53.7\% of the gall morphotypes sampled in the present study, which suggests that these orders are highly important to galling insects. However, the galling insect species richness was also relatively high among the orders Ericales, Sapindales and Rosales, which presented with nine, six and four gall morphotypes, respectively.

Various authors, such as Gagné (1994) and Mendonça (2007), have analyzed the importance of gall host taxa at the family level. In the present study, the families most commonly represented, in descending order, were Fabaceae, Styracaceae, Vochysiaceae, Myrtaceae, Euphorbiaceae,

Table 1. Areas and vegetation formations within which galls were sampled in the state of Goiás, Brazil. 2005-2007.

\begin{tabular}{|c|c|c|c|}
\hline Study area & Type(s) of vegetation formation $(\mathrm{s})^{*}$ & Municipality & $\begin{array}{l}\text { Geographic } \\
\text { coordinates }\end{array}$ \\
\hline Serra dos Pireneus State Park & $\begin{array}{c}\text { Cerrado (savanna) stricto sensu, rocky cerrado, dry } \\
\text { semideciduous forest, gallery forest }\end{array}$ & Pirenópolis, Goiás & $\begin{array}{l}15^{\circ} 47^{\prime} 34.4^{\prime \prime} \mathrm{S} ; \\
48^{\circ} 50^{\prime} 16.3^{\prime \prime} \mathrm{W}\end{array}$ \\
\hline Semi-urban region & Cerrado stricto sensu, cerradão (woodland savanna) & Goiânia, Goiás & $\begin{array}{l}16^{\circ} 35^{\prime} 53.98^{\prime \prime S} \\
49^{\circ} 16^{\prime} 51.1^{\prime \prime} \mathrm{W}\end{array}$ \\
\hline Semi-urban region & Cerrado stricto sensu & Caldas Novas, Goiás & $\begin{array}{l}17^{\circ} 44^{\prime} 41.9^{\prime \prime} \mathrm{S} ; \\
48^{\circ} 37^{\prime} 29.8^{\prime \prime} \mathrm{W}\end{array}$ \\
\hline Campus of the Federal University of Goiás & Dry semideciduous forest & Goiânia, Goiás & $\begin{array}{l}16^{\circ} 36^{\prime} 12.9^{\prime \prime} \mathrm{S} \\
49^{\circ} 15^{\prime} 41.7^{\prime \prime} \mathrm{W}\end{array}$ \\
\hline
\end{tabular}

${ }^{*}$ Classifications based on Ribeiro \& Walter (1998). 
Table 2. Number of host plant species and gall morphotypes per host plant family in different areas of the cerrado (savanna) in the state of Goiás, Brazil.

\begin{tabular}{|c|c|c|}
\hline Plant family & Number of host species & Number of gall morphotypes \\
\hline Fabaceae & 12 & 17 \\
\hline Styracaceae & 2 & 7 \\
\hline Vochysiaceae & 3 & 6 \\
\hline Myrtaceae & 4 & 5 \\
\hline Euphorbiaceae & 4 & 4 \\
\hline Malpighiaceae & 4 & 4 \\
\hline Ulmaceae & 2 & 4 \\
\hline Bignoniaceae & 2 & 3 \\
\hline Sapindaceae & 1 & 3 \\
\hline Malvaceae & 2 & 2 \\
\hline Melastomataceae & 2 & 2 \\
\hline Asteraceae & 2 & 2 \\
\hline Burseraceae & 1 & 2 \\
\hline Piperaceae & 1 & 2 \\
\hline Dilleniaceae & 1 & 2 \\
\hline Anacardiaceae & 1 & 1 \\
\hline Annonaceae & 1 & 1 \\
\hline Apocynaceae & 1 & 1 \\
\hline Araliaceae & 1 & 1 \\
\hline Caryocaraceae & 1 & 1 \\
\hline Chrysobalanaceae & 1 & 1 \\
\hline Clusiaceae & 1 & 1 \\
\hline Ebenaceae & 1 & 1 \\
\hline Erytroxylaceae & 1 & 1 \\
\hline Lauraceae & 1 & 1 \\
\hline Loranthaceae & 1 & 1 \\
\hline Monimiaceae & 1 & 1 \\
\hline Ochnaceae & 1 & 1 \\
\hline Proteaceae & 1 & 1 \\
\hline Sapotaceae & 1 & 1 \\
\hline Total & 58 & 80 \\
\hline
\end{tabular}

Malpighiaceae, Ulmaceae, Bignoniaceae, Sapindaceae and Malvaceae (Fig. 2b). Many of those are the families with the greatest numbers of neotropical species, especially within the cerrado biome (Mendonça et al. 1998). According to Gagné (1994), Fabaceae is the family in which the diversity of morphotypes of galls induced by Cecidomyiidae (Diptera) in the neotropical region is greatest. Fabaceae has also been shown to have higher species richness than does any other family within the cerrado biome (Mendonça et al. 1998).

Although Styracaceae and Vochysiaceae were well represented in the present study, neither Gagné (1994) nor Mendonça (2007) mentioned them among the most representative families. Within the cerrado, Styracaceae and Vochysiaceae are represented by only nine and 36 species, respectively (Mendonça et al. 1998). Nevertheless, in the present study, they were among the families showing the greatest galling insect species richness, because of the number and diversity of galls affecting the genera Styrax and Qualea, respectively. In terms of the number of gall morphotypes, the family Myrtaceae ranked fourth in the present study, whereas it ranked fifth and second in the studies conducted by Gagné (1994) and Mendonça (2007), respectively. Myrtaceae is the seventh most diverse family in the cerrado (Mendonça et al. 1998).

We found a positive correlation between the size of the plant family (in number of species) and galling insect species richness (Fig. 3), plant family size explaining $49 \%$ of the variation in the number of galls $\left(\mathrm{r}^{2}=0.49, \mathrm{~N}=30, \mathrm{p}<0.001\right)$. This pattern was strongly influenced by Fabaceae, which showed the greatest species richness, in terms of host plants of galls in the cerrado (Mendonça et al. 1988). These results support the plant family size hypothesis, which states that the 

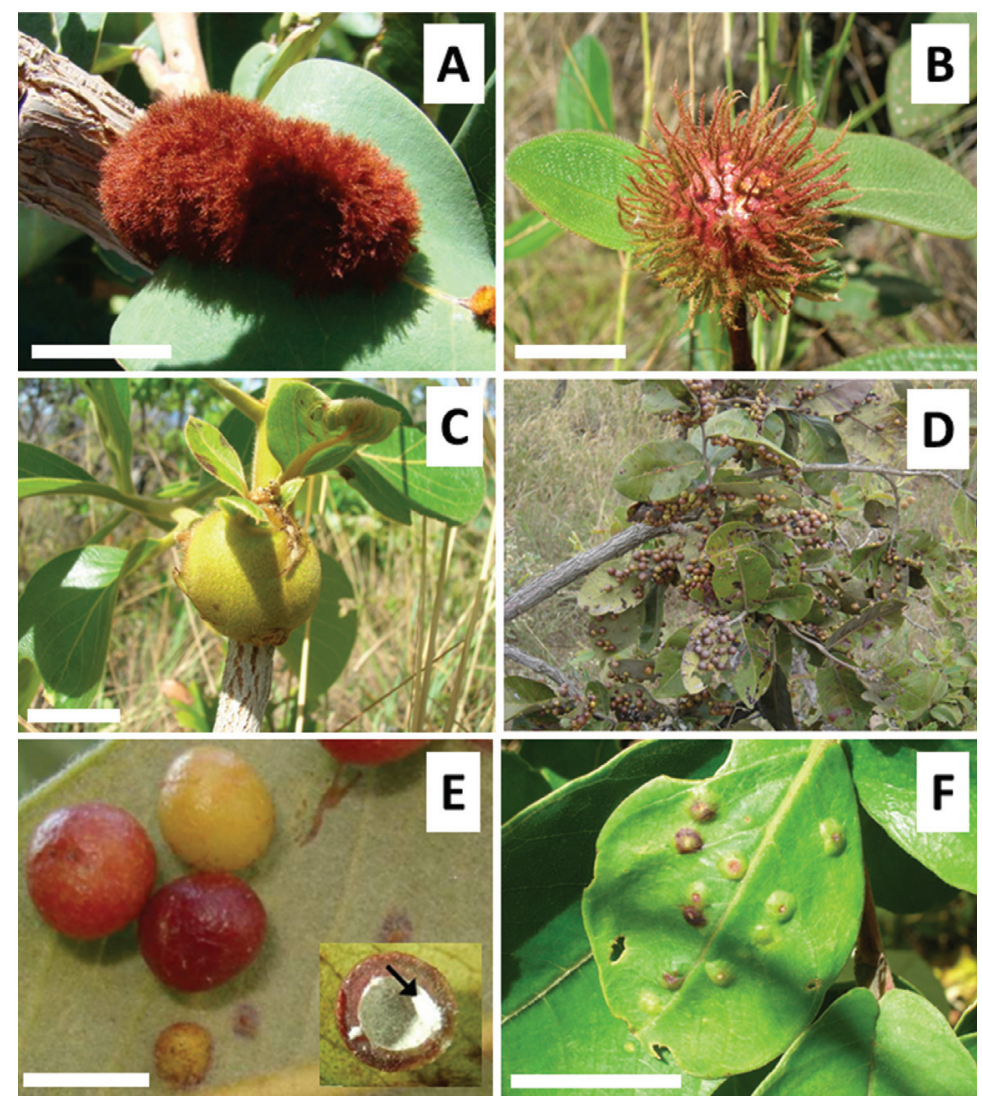

Figure 1. Examples of insect-induced galls found in different areas of cerrado (savanna) in the state of Goiás, Brazil: A) globose leaf gall of Cecidomyiidae (Diptera) on Erythroxylum suberosum; B) globose leaf gall of Gelechiidae (Lepidoptera) on Macairea radula; C) globose stem gall of Lepidoptera on Diospyros hispida; D) general aspect of the plant Psidium pohlianum replete with leaf galls of Psyllidae (Hemiptera); E) open gall on Psidium pohlianum showing the inner compartment with the insect nymph (arrow); and F) on Qualea parviflora, discoid leaf galls caused by parasitoids (Hymenoptera), rather than galling insects. Scale bar: $2 \mathrm{~cm}$ in A-D and F; $0.5 \mathrm{~cm}$ in $\mathrm{E}$.

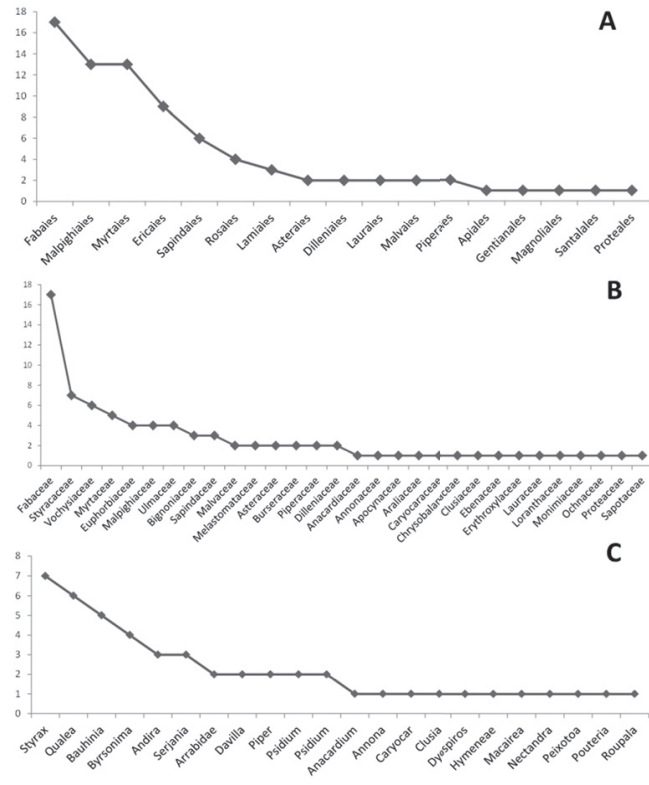

Figure 2. Distribution of galling insect species richness (number of galling species per host plant taxon) in various areas of the cerrado (savanna) in the state of Goiás, Brazil: a) by order; b) by family; and c) by genus.

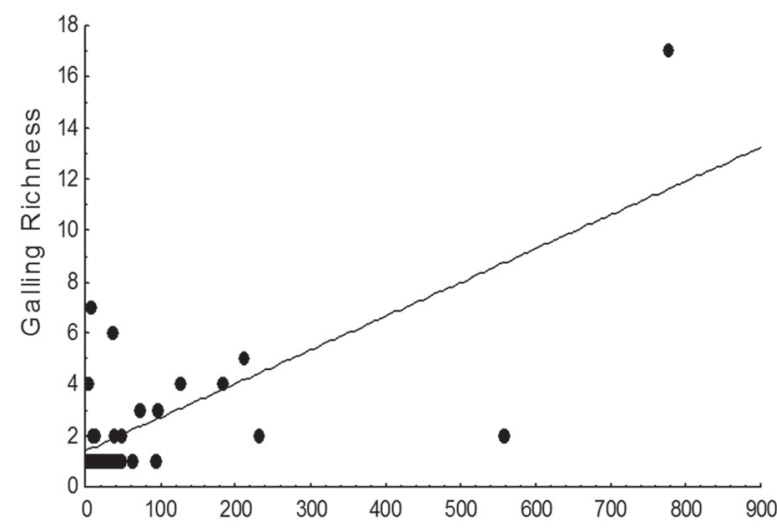

Figure 3. Linear regression between galling insect species richness per plant taxon and plant family size in number of species $\left(y=1.39+0.01 x, r^{2}=0.49, \mathrm{~N}=\right.$ 30, $\mathrm{p}<0.001$. Data on family size taken from Mendonça et al. (1998). 
diversity of galling insects should be greater among the host plant families with the highest numbers of species (Fernandes 1992; Araújo 2011; Araújo et al. 2012). A high number of species within a family creates a greater availability of niches available for galling (Mendonça 2007). Gonçalves-Alvim \& Fernandes (2001) found galling insect species richness to be higher among plant families that comprise more species. The authors showed that $50 \%$ of the variation in galling insect species richness was explained by the size of the plant family and that the five major families (Leguminosae, Asteraceae, Myrtaceae, Malpighiaceae, and Erythroxylaceae) harbored more than $65 \%$ of the galls identified.

Among the 47 genera of host plants of galls sampled in the present study, galling insect species richness was found to be highest for the genera Styrax, Qualea, Bauhinia and Inga (Fig. 2c). Styrax was the only representative of the family Styracaceae with seven morphotypes of galls, six of them being on Styrax pohlii DC, a species known to present great galling insect species richness (Araújo \& Santos 2009b; Araújo et al. 2012). Likewise, Qualea was the only Vochysiaceae genus of presenting six morphotypes. Qualea parviflora Mart. hosted five of the six morphotypes of galls of that genus, confirming the results recently reported by Araújo et al. (2013), who classified the genus Qualea as a "superhost" of insect galls.

All of these observations indicate that the diversity of galls depends on a local component: the composition of the plant community (Vedtman \& McGeoch 2003). The composition of the plant community is a qualitative character given by the identity of the taxon (Begon et al. 2006), which is considered a determinant of the character of different communities and vegetation formations (Scarano 2002). In addition, at the family or genus level, the presence of certain taxa appears to increase galling insect species richness (Gonçalves-Alvim \& Fernandes 2001; Araújo et al. 2012).

Certain plants families have been frequently identified in studies of insect-induced gall diversity in Brazil, indicating their importance as host groups. For example, the family Myrtaceae is frequently listed in surveys of galls in the Atlantic Forest of southeastern Brazil (Maia 2001; Maia et al. 2008). it has been reported that, for the southern region of Brazil, which is dominated by Atlantic Forest and Pampas, galling insect species richness is greatest among host plants of the family Asteraceae (Mendonça 2007), whereas, in the cerrado, it is greatest among those of the family Fabaceae (Gonçalves-Alvim \& Fernandes 2001; Maia \& Fernandes 2004; Araújo et al. 2012). In a preliminary study of gall diversity in Goiás, Araújo et al. (2007) also found galling insect species richness to be highest among host plants of the family Fabaceae. These patterns are repeated at the genus level. In a broad revision of the galling fauna associated with the genus Baccharis (Asteraceae), Fernandes et al. (1996) registered 121 gall morphotypes. Mendonça (2007) found 19 and 15 gall morphotypes on host plants of the genera Mikania (Asteraceae) and Eugenia (Myrtaceae), respectively.
Araújo et al. (2013) recently reported 19 gall morphotypes on host plants of the genus Qualea (Vochysiaceae) occurring in diverse areas of the cerrado. In the present study, the number of gall morphotypes was found to be highest $(\mathrm{n}=7)$ for host plants of the genus Styrax (Styracaceae). The high diversity of galls on host plants of these genera can have a considerable influence on the local diversity of galling insects (Oyama et al. 2003; Araújo et al. 2012; Araújo et al. 2013).

According to Moreira (2006), approximately 40\% of all studies of insect-induced galls in Brazil are related to insect taxonomy and diversity, whereas another $40 \%$ deal with the biology and ecology of galling. The diversity of insect-induced galls, with an emphasis on the composition and structure of plant communities, has come to be studied only recently in Brazil (Mendonça 2007). We recommend that botanists and plant ecologists collect data on insect-induced galls during their fieldwork. The galls are easy to collect, and the insects they harbor can be bred to maturity (for identification) in the laboratory, a process that, albeit laborious, is not expensive or complicated (see methodologies of sampling in Price et al. 1998). During the collection of botanical specimens, the occurrence of galls is often ignored, which limits our knowledge of the variety of these interactions and contributes to the lack of data in the literature. Studies of the occurrence and characteristics of galls are fundamental to understanding the diversity patterns of galling insects and their host plants. In addition, the gall morphotypes are extremely specific and could be used for taxonomic differentiation between closely related or similar plant species (Abranhamson et al. 1998).

The host plants of galls are determinants of galling insect diversity, because the former provide the conditions and fundamental resources necessary for the development of the offspring of the latter, especially habitat and food (Mendonça 2001). Each species of host plant represents a potential niche for galling insects (Mendonça 2007), some of them being considered "superhosts" of galls (Vedtman \& McGeoch 2003). All of this underscores the need to seek a deeper knowledge of the flora that hosts galls, in terms of its composition and diversity. Therefore, efforts to identify the diversity patterns of galling insects must also consider that of their host plants.

\section{Acknowledgments}

The authors are grateful to Frederico Augusto Guimarães Guilherme, of the Universidade Federal de Goiás (UFG, Federal University of Goiás), and to the peer reviewers, for their suggestions to improve the manuscript, as well as to the UFG Biological Sciences Institute, for the logistical support provided. This study received financial support from the Brazilian Coordenação de Aperfeiçoamento de Pessoal de Nivel Superior (CAPES, Office for the Advancement of Higher Education; grant to WSA). 


\section{References}

Abrahamson, W.G.; Melika, G; Scrafford, R. \& Csóka, G. 1998. Gallinducing insects provide insights into plant systematic relationships. American Journal of Botany 85: 1159-1165.

APG II. 2003. An update of the Angiosperm Phylogeny Group classification for the orders and families of flowering plants. Botanical Journal of the Linnean Society 141: 399-436.

Araújo, W.S. 2011. Size, age and composition: characteristics of plant taxa as diversity predictors of gall-midges (Diptera: Cecidomyiidae). Revista Biologia Tropical 59: 1599-1607.

Araújo, W.S. \& Santos, B.B. 2009a. Efeitos da sazonalidade e do tamanho da planta hospedeira na abundância de galhas de Cecidomyiidae (Diptera) em Piper arboreum (Piperaceae). Revista Brasileira de Entomologia 53: 300-303

Araújo, W.S. \& Santos, B.B. 2009b. Complexidade estrutural e diversidade de insetos galhadores em Styrax pohlii Fritsch (Styracaceae). Bioscience Journal 25: 181-184.

Araújo, W.S.; Santos, B.B.; Ferreira, H.D. \& Lousa, T.C. 2007. Ocorrência de galhas entomógenas na vegetação do Campus da UFG, em Goiânia, Goiás. Revista Brasileira de Biociências 5: 57-59.

Araújo, W.S.; Santos, B.B. \& Gomes-Klein, V.L. 2012. Relationship between host plant diversity and gall-inducing insects richness in the Brazilian Cerrado. Neotropical Biology and Conservation 7: 41-47.

Araújo, W.S.; Scareli-Santos, C.; Guilherme, F.A.G.; Cuevas-Reyes, P. 2013. Comparing galling insect richness among Neotropical savannas: effects of plant richness, vegetation structure and super-host presence. Biodiversity and Conservation 22: 1083-1094.

Begon, M.; Townsend, C. \& Harper, J.L. 2006. Ecology: from individuals to ecosystems. Blackwell Publishing, Oxford. 738p.

Carneiro, M.A.A.; Branco, C.S.A.; Braga, C.E.D.; Almada, E.D.; Costa, M.B.M.; Maia, V.C. \& Fernandes, G.W. 2009. Are gall midge species (Diptera, Cecidomyiidae) host-plant specialists? Revista Brasileira de Entomologia 53: 365-378.

Cuevas-Reyes, P.; Quesada, M.; Hanson, P. Dirzo, R. \& Oyama, K. 2004. Diversity of gall-inducing insects in a Mexican tropical dry forest: the importance of plant species richness, life-forms, host plant age and plant density. Journal of Ecology 92: 707-716.

Espírito-Santo, M.M. \& Fernandes, G.W. 2007. How many species of galling insects are there on earth and where they are? Annals of the Entomologycal Society of America 100: 95-99.

Espírito-Santo, M.M.; Neves, F.S.; Andrade-Neto, F.R. \& Fernandes, G.W. 2007. Plant architecture and meristem dynamics as the mechanisms determining the diversity of gall-inducing insects. Oecologia 153: 353-364.

Fernandes, G.W. 1992. Plant size family and age effects on insular gallforming species richness. Letters in Global Ecology and Biogeography 2: 71-74.

Fernandes, G.W. \& Price, P.W. 1988. Biogeographical gradients in galling species richness: tests of hypotheses. Oecologia 76: 161-167.

Fernandes, G.W.; Carneiro, M.A.A.; Lara, A.C.F.; Allain, L.A.; Andrade, G.I.; Julião, G.; Reis, T.C. \& Silva, I.M. 1996. Galling insects on neotropical species of Baccharis (Asteraceae). Tropical Zoology 9: 315-332.
Fernandes, G.W.; Neto, E.T. \& Martins, R.P. 1988. Ocorrência e caracterização de galhas entomógenas na vegetação do Campus Pampulha da Universidade Federal de Minas Gerais. Revista Brasileira de Zoologia 5: 11-29.

Gagné, R.J. 1994. The gall midges of the Neotropical region. Ithaca, Cornell University Press.

Gonçalves-Alvim, S.J. \& Fernandes, G.W. 2001. Biodiversity of galling insects: historical, community and habitat effects in four neotropical savannas. Biodiversity and Conservation 10: 79-98.

Maia, V.C. 2001. The gall midges (Diptera, Cecidomyiidae) from three restingas of Rio de Janeiro State, Brazil. Revista Brasileira de Zoologia 18: 583-629.

Maia, V.C. \& Fernandes, G.W. 2004. Insect galls from Serra de São José (Tiradentes, MG, Brazil). Brazilian Journal of Biology 64: 1-22.

Maia, V.C.; Magenta, M.A.G. \& Martins, S.E. 2008. Ocorrência e caracterização de galhas de insetos em áreas de restinga de Bertioga (São Paulo, Brasil). Biota Neotropica 8: 167-197.

Mendonça, M.S. 2001. Galling insect diversity patterns: the resource synchronization hypothesis. Oikos 95: 171-176.

Mendonça, M.S. 2007. Plant diversity and galling arthropod diversity searching for taxonomic patterns in an animal-plant interaction in the Neotropics. Boletín de la Sociedad Argentina de Botánica 42: 347-357.

Mendonça, R.C., Felfili, J.M., Walter, B.M.T., Silva Júnior, M.C., Rezende, A.V., Filgueiras, T.S. \& Nogueira, P.E. 1998. Flora Vascular do Cerrado. Pp. 289-556. In.: Sano, S.M. \& Almeida, S.P. (Eds.). Cerrado: ambiente e flora. Brasília, Embrapa/CPAC.

Moreira, G.R.P. 2006. Galhas entomógenas no Brasil: oportunidade de estudo sobre interação inseto-planta. p. 532-537. In: Mariath, J.E.A. \& Santos, R.P. (Orgs.). Os avanços da botânica no século XXI. Congresso Nacional de Botânica, 57, Gramado, RS. Anais.

Oliveira, J.C. \& Maia, V.C. 2006. Ocorrência e caracterização de galhas de insetos na Restinga de Grumari (Rio de Janeiro, RJ, Brasil). Arquivos do Museu Nacional 63: 669-675.

Oyama, K.; Pérez-Pérez, M.A.; Cuevas-Reyes, P. \& Luna-Reyes, L. 2003. Regional and local species richness of gall-inducing insects in two tropical rain forests in Mexico. Journal of Tropical Ecology 19: 595-598.

Price, P.W.; Fernandes, G.W.; Lara, A.C.F.; Brawn, J.; Gerling, D.; Barrios, H.; Wright, M.; Ribeiro, S.P. \& Rothcliff, N. 1998. Global patterns in local number of insect galling species. Journal of Biogeography 25: 581-592

Price, P.W. 2005. Adaptive radiation of gall-inducing insects. Basic and Applied Ecology 6: 413-421.

Ribeiro, J.S. \& Walter, B.M.T. Fitofisionomias do bioma Cerrado. Pp. 89166. In.: Sano, S.M. \& Almeida, S.P. (Eds.). Cerrado: ambiente e flora. Brasília, Embrapa/CPAC.

Scarano, F.R. 2002. Structure, function and floristic relationships of plants communities in stressful habitats marginal to the Brazilian Atlantic Rainforest. Annals of Botany 90: 517-524.

Stone, G.N. \& Schönrogge, K. 2003. The adaptive significance of insect gall morphology. Trends in Ecology \& Evolution 18: 512-522.

Vedtman, R. \& McGeoch, M.A. 2003. Gall-forming insect species richness along a non-scleromorphic vegetation rainfall gradient in South Africa: the importance of plant community composition. Austral Ecology 28: 1-13. 